\title{
MEDIA COMMUNICATION IN THE GLOBAL SOCIETY
}

\author{
Hanne-Lore Bobáková ${ }^{1}$, Květuše Mozielowskáa ${ }^{2}$ \\ ${ }^{1}$ Slezská univerzita, Obchodně podnikatelská fakulta, Univerzitní nám. 1934/3,73340 Karviná \\ Email:bobakova@opf.slu.cz \\ ${ }^{2}$ Slezská univerzita, Obchodně podnikatelská fakulta, Univerzitní nám. 1934/3,73340 Karviná \\ Email:mozielowska@opf.slu.cz
}

\begin{abstract}
The article deals with the characteristics of today's media communication. In the introduction attention is drawn to some aspects of media communication. Media communication is described here as a part of global society where the importance of persuasion is growing. The issues of persuasion, persuasive techniques, and modality of advertising texts are further analysed, using examples from German advertising texts. The article is based on the analysis of German media advertising texts gained from long-time excerpts, from two years of the Austrian magazine Freizeit Kurier from 2007 to 2008. To analyse the advertising texts the advertising slogans from the internet were also used. Their research was focused on their lexical and text aspects.
\end{abstract}

Keywords: marketing communication, means of persuasion, media communication, modality of advertising, persuasion.

JEL classification: Y80

Doručeno redakci: 28.3.2011; Recenzováno: 8.1.2013; 18.1.2013; Schváleno k publikování: 13.3.2013

\section{Introduction}

The number of publication outputs focused on communication issues is considerably extensive. Their contentual focus is influenced by pragmatic aspects of the applicability of these outputs in practice. ${ }^{1}$ The common factor for the latest publications in the area of communication is the effort to teach rhetorical skills, persuasive or dirty techniques in communication, frequently referred to as manipulation.

In our pilot study the actual media communication issues are focused on from the point of view of the recipient's security. The power of words is magic and communication proportions can have fatal consequences for both the individual and the whole society. Here the growing imperativeness in media communication and related consumer way of life are meant. We agree with Klapetek on regarding the multidimensionality of the concept word and communication in general:

"All our words and our every speech occur in a new complex communication space which is given by the informatively connected world with countless numbers of communication patterns, none of which is however general. In our new situation it is however fortunately often possible to make use of knowledge of sciences which deal with the very nature of information as well as sciences that have managed to reveal the secret of the function of human mind and soul." (Klapetek, 2008, 10).

The power of word is dealt with in this whole study. We make use of knowledge of linguistics, communication theory, psychology, sociology, culturology, and knowledge of media communication in context connections.

\footnotetext{
${ }^{1}$ e.g. FLUME, P. Rétorika v praxi (2008), KLAPETEK, M. Komunikace, argumentace, rétorika (2008).
} 
The importance of media communication is undubitable, it uses words as its instrument for mass manipulation (Klapetek, 2008, 136). It would be incorrect to assume that manipulation is only a postmodern society product. Only its aggressiveness and persuasion change. When omitting the political and economic aspect of media communication, its psychological and sociological extension is not insignificant.

Lehoczká $(2010,19)$ speaks already about the dynamic substance of the mass communication media system by means of which it adapts to the changes of social development. In this context it is therefore necessary to understand the globalization process in media better and to protect the safety of the own value system, one's conviction and opinions.

If we look at the media communication at the beginning of the 1990s and at the beginning of the $21^{\text {st }}$ century we can notice that today media communication is much more connected with social changes than any other area of communication. It is open towards the operation of foreign languages, especially the operation of the English language. It is advisable to define the phenomenon called language internationalization. The Encyclopedic dictionary of the Czech language distinguishes between europeisms and internationalisms. Europeisms are expressions which often originate from Greek and Latin and are used throughout Europe. Internationalisms are widespread throughout the world. ${ }^{2}$ In this study we start from the definition of internationalism as an integrated unit of different complexity (word, morpheme, construction) by means of which the formally congruent, contentually equivalent units of particular languages are formed. Buzassyová $(2003$, 6) mentions the fact that contentual equivalence includes semantic closeness and relatively close communication and functional validity of internationalisms.

It is quite evident that even marketing communication has not avoided the internationalization process. It takes over new notions and terms in the area of special scientific marketing communication and in special areas of advertising, such as tourist traffic advertising, media advertising, etc. The internationalization process constitutes a trend in the lexicon development of European languages. Lotko has the same standpoint, too. He emphasizes the fact, that in every stage of a living language it is possible to discover certain development trends, i.e. the direction a particular language phenomenon proceeds (Lotko, 1999, 349).

\section{Persuasive techniques of media communication}

Modern communication technologies permeate the world of both the individual and the whole society. They constitute the conveniences of the modern world but they can also have negative aspects. In the following part the persuasive techniques of media communication are focused on.

Persuasion is understood as a certain kind of convincing often bordering on manipulating techniques. Various types of arguments, the social dimension of argumentation and not least the moral aspects of the influencing attempts of the media world are noticed here. Media texts have become part of our lives and hardly anyone realizes their impact on the individual and the society. As a result the number of publications on this topic is increasing from both the marketing and the linguistic points of view.

\footnotetext{
${ }^{2}$ In the Encyclopedic dictionary it is stated that the differences between europeisms and internationalisms are vanishing at present.
} 
Information which has evident character of goods enters human lives by means of media. According to Lehoczká $(2010,20)$ the postmodern principle of mediation of actual information in the form of goods in mass media environment can be characterised at the level of mass media ritual: in the hands of mass media corporations the information becomes an object of an intentionally created simulation, respectively a constructed pseudoreality which affects attitudes, opinions and behaviour of the individual considerably and which influences the cognitive activity, life style and taste.

\section{Terminological resources}

In our study we start from Dijk's concept of persuasion and manipulation. In accordance with his concept we can see different associations in the connotation of the terms persuasion and manipulation, which leads to associations of a negative type by manipulative techniques (van Dijk, 2006, 361).

We have to state that van Dijk's concept of persuasion and manipulation was applied to the analysis of political discourse, nevertheless we are clear about the possibility of its application to the analysis of media communication focused on advertising texts. General questions of advertising texts, respectively the bearer of advertising are omitted here. The focus is on a detailed analysis of the language form and its advertising strategy. In this pilot study excerptions of advertising texts of two annual sets of the Austrian magazine Freizeit Kurier from the years 2007 and 2008 are used. For the analysis of advertising texts the advertising slogans from the internet were used too. The explicit research of Austrian advertising texts was restricted to the ways of persuasive techniques and their impact on the recipient. The aim of this study is to map the extent of these techniques and to evaluate their impact on the safety of the individual.

\section{The raise of persuasion by the help of lexical means}

When analyzing Austrian advertising texts the frequent use of persuasive techniques based on various lexical means was observed. The use of numeric identifiers was striking:

(1) Schönheit ist Vertrauen.

Doppelt so viel $Q 10$

Doppelte Anti-Falten-Kraft

Bekämpfen Sie Hautalterung jetzt noch effektiver.

Verringert Fältchen in wenigen Stunden

Mildert Mimikfalten in 3 Wochen

Reduziert die Tiefe ausgeprägter Falten nach 4 Wochen

(Magazin 968, 21. 6. 2008, p. 15) In some advertising texts the proper punctuation was missing.

In the above mentioned advertising the numeral identifiers are used at a few levels at the same time. These levels can be characterized as follows:

- Intensification of the effect by means of a numeral (doppelt so viel)

- Intensification of the advertising function by means of an adjective and an adverb (jetzt noch effektiver)

- $\quad$ Mention of time horizon of the demanded effect (in 3 Wochen, nach 4 Wochen)

It is evident that the use of more lexical means with persuasive effect raises the total persuasion of the text. In this excerption synclitism was found. The use of adjectives is interesting, too, e.g. das neuartige Gefühl mit ihrem neuartigen Wirkstoff-Komplex (see below advertising cream Scholl): 
(2) Scholl Anti-Hornhaut Creme Intensiv

Erleben Sie das neuartige Gefühl befreiter Haut!

Reduzieren Sie Hornhaut sichtbar in nur 7 Tagen.

Mit sofort spürbarem Pflege-Effekt.

(Magazin 968, 21. 6. 2008, p. 51)

We cannot omit the fact that the significance of adjectives and adverbs in advertising texts is unreplaceable, especially in the strengthening of the persuasive function of the text. Their choice is limited to such connotations which serve the overstatement, exaggeration and glamorizing of the given reality. Below the excerpted examples follow:

Göttliche Lage, faszinierende Wimpern, grenzenlose Möglichkeiten, strahlende Bräune, hochwirksamer Sonnenschutz, feuchtigkeitsspendende Substanzen, meisterlich gute Mehlspeisen, ertragsreichste Veranlagungsmöglichkeiten, sinnlichste Seite des Lebens, Leidenschaft auf höchstem Niveau, unwiderstehliche Magnum Schokolade, verführerisch zarte Eiscreme, der belebender Duft, edles Design, kompromisslose Vorgehensweise, außergewöhnlich komfortabel, ungewöhnlich persönlich, maximale Feuchtigkeitsversorgung, beste Qualität zum besten Preis, duftende Kaffespezialitäten, jugendliche Ausstrahlung, schmeichelnde Farbnuancen, köstlicher Schatz, brillante Farben, atemberaubende Details, ausgezeichneter Geschmack, exklusive Einrichtung, für virtuosen Schwung, das neuartige Gefühl and other.

The analysis of advertising texts showed that the force of persuasion can be achieved even by imperative techniques. The imperative character of communication combined with punctuation notes (in this case the note of exclamation) raises the evocation of a totally safe feeling (für ein rundum beruhigendes Gefühl):

(3) EVVA (advertising alarm)

Schutz für alles Liebe und Teure.

Hochwertige Alarmanlagen.

Schützen Sie sich mit dem EVVA vor dem Zutritt unberechtigter Personen!

Wir sind Marktführer in Österreich und Ihr innovativer Partner in allen Sicherheitsfragen vom mechanischen oder elektronischen Schließsystem bis zur individuell abgestimmten Alarm-und Videoanlagen. Für ein rundum beruhigendes Gefühl! (Magazin 968, 21. 6. 2008, p. 91)

\section{Persuasion of three arguments}

The use of three emphatic arguments, e.g. three adjectives in advertising the filling in the appliance Dolce Gusto, is a relatively frequent and effective technique:

(4) Dolce Gusto

Manche mögen's heiß!

Eiskalter Kaffeegenuss im Handumdrehen

- Vielseitig

- Verführerisch

- Aromatisch vollendet durch 14 bar Profidruck

(Magazin 958, 19. 4. 2008, p. 123)

The technique of tree arguments is often used in combination with the factuality of data, by which the effect of persuasion is raised:

(5) OMNI-BIOTIC PANDA (advertising probiotic nutrition)

Für ein gesundes Leben und das meines Kindes.

Gesundheit beginnt im Darm. 
Für die Regeneration und den Aufbau einer gesunden Darmflora wurde OMNIBIOTIC PANDA entwickelt. Das Probiotikum für Mutter und Kind, dessen Eignung wissenschaftlich geprüft und getestet wurde.

- Frei vom tierischen Eiweiß

- Ohne Zucker, Glute, Hefe und Laktose

- Für Diabetiker, Milchallergiker und laktoseintollerante Menschen geeignet. (Magazin 958, 19. 4. 2008, p. 99)

The factuality of expression is used to raise the persuasion often by means of numeral indications (the numbers of companies, employees, customers). Numeral arguments can convince the readers to buy the product, to make use of the given service, etc.:

(6) VIENNA INTERNATIONAL AIRPORT (advertising international airport in Vienna) 18000 Mitarbeiter, ein Ziel: Ihre angenehme Reise.

Egal, ob Sie in den Urlaub oder zu einem Geschäftstermin fliegen - 18000 Beschäftigte in rund 230 Betrieben kümmern sich am Flughafen Wien um Pünktlichkeit, Komfort und Sicherheit. Mit den Investitionen der Flughafen Wien AG werden jährlich Hunderte weitere Arbeitsplätze geschaffen. Zugleich wird sichergestellt, dass heuer rund 20 Millionen Passagiere ihr Ziel im In- und Ausland bequem und rasch erreichen werden.

(Magazin 960, 26. 4. 2008, p. 63)

\section{Persuasive techniques of negating messages}

Besides above mentioned persuasive techniques the significance of negating media release will be mentioned here. A frequent phenomenon is the use of certain verbs, e.g. the verb it will not do .../es reicht nicht aus ..., which must necessarily lead to impeachment of the attitude of the individual towards the respective reality and to accession to this intentionally created manipulative game of postmodern time. Several examples from our excerption follow:

(7) Der Aufbau von Kollagenfasern alleine reicht nicht, um ausgeprägte Falten aufzufüllen.

(Magazin 930, 29. 9. 2007, p. 4.)

(8) Verlieren Sie keine Zeit - schützen Sie Ihr Kind - und lassen Sie es bereits im Säuglingsalter gegen Pneumokokken impfen.

(Magazin 929, 22. 9. 2007, p. 35.)

(9) Sie wollen nicht länger auf Brillen oder Kontaktlinsen angewiesen sein? (Magazin 929, 22. 9. 2007, p. 33.)

(10) Keiner schützt die ganze Familie besser.

(Magazin 960, 26. 4. 2008, p. 123.)

A negating message constitutes a high rate of persuasion. In combination with the superlatives of adverbs the reader is affected by an advertising text which shall evoke his conviction that there is not any other possible choice. In such cases the advertising text is very close to manipulative persuasion.

\section{Modality of advertising texts}

Another relatively frequent means to achieve the persuasive effect is modality. The factual component of advertizing media release constitutes the offer of goods or services with the aim to persuade the potential customer of the merits of an offered product. It is therefore quite 
understandable that he is offered such information which raises his readiness to buy goods or to make use of a respective service. Strategies exist about the truthfulness of statements supported by attested documents with scientific or medical studies confirming the declared reality in the media release.

Of course this reality is reflected in the text by different degrees of modality. The effect of persuasion is naturally stronger by the epistemic type of modality, that is why it is frequently used in these media texts. Examples below from our excerption follow:

(11) $73 \%$ bewiesene Wirksamkeit. Klinische Tests beweisen eine sichtbare Besserung des Orangenhauteffekts ab der 8. Woche (19.4. 2008, p. 105.)

(12) Das Probiotikum für Mutter und Kind, dessen Eignung wissenschaftlich geprüft und bestätigt wurde (19.4. 2008, p. 105).

(13) Unabhängige Institute bestätigen reinste Qualität (19.4. 2008, p. 99).

(14) $85 \%$ der Testpersonen bestätigen eine Verbesserung stark verhornter Hautpartien bereits nach wenigen Tagen (21.6. 2008, p. 51).

(15) Die Testergebnisse von 30 Frauen wurden von einem Expertenteam ausgewählt (19.4. 2008, p. 53).

(16) Dermatologische Tests unterstreichen die ausgezeichnete Hautverträglichkeit von Hydrofugal (14.6. 2008, p. 87).

(17) Klinische Studien beweisen die ausgezeichnete Hautverträglichkeit - selbst an den sensibelsten Körperteilen (14.6. 2008, p. 47).

\section{Conclusion}

If we sum up the possibilities of the use of persuasive techniques in advertising texts we can state that their extent is relatively rich. It includes lexical, syntactic, grammatical, stylistic, rhetorical and psychological aspects of influencing the recipient. From the lexical point of view we noticed the influence of numeral identifiers first and the specific role of adjectives and adverbs in the intensive living of the advertising text. From the grammatical point of view we focused on imperative techniques, negating messages and modality expressions and pointed out to their persuasive function. At the stylistic and semantic levels we emphasised the importance of factual argumentation and the ways leading to optimal persuasion. We mentioned the importance of factual argumentation based on research, investigation, scientific analyses, experiments, etc.

An important part of persuasive techniques is the use of psychological aspects of the effect of advertising texts on the recipient and its ability to evoke quite new needs, desires and wishes according to the spirit of the creation of new values, a new life style and moral principles. In this direction a question occurs asking about safety of a media text for the recipient by reason of potential or apparent danger for both the individual and the society. The desire to live according to the spirit of the new life style, surrounded by luxury, superfluous things and apparently outer physical perfection of the individual could easily become the only sense of human existence. In the conception of the world created in such an illusory way the real life values could lose their meaning. 
It is beyond dispute that media communication is subject to the process of modernization, mass and globalization most. The aim of this study was to emphasize the multidimensional character of communication and to follow the specific pragmatic intention. In this context the psycho-, socio- and pragmalinguistically conditioned communication cannot be omitted and the fact must be emphasized that any interpersonal communication cannot be examined objectively without the acceptance of extralingual, individual and social aspects. (Patráš, 2009, p. 47).

In conclusion it is necessary to mention the importance of media communication. Thanks to its style composition and balanced combination of apparently unsubstantial details the media communication participates in the co-creation of the product. It influences human conduct, affects social communication and not least it changes cultural values and human attitudes.

\section{References}

[1] VAN DIJK, T. Discourse and manipulation. Discourse and Society, Vol 17 (2), p. 359383, accessible at: http://www.discourse.org/download/articles/.

[2] KLAPETEK, M., 2008. Komunikace, argumentace, rétorika. Praha: Grada. 247p. ISBN 978-80-247-2652-6.

[3] LEHOCZKÁ, V., 2010. Dimenze profesionality súčasnéj masmediálnej komunikácie. In: Communication Today. Trnava: FMK UCM. 156 p. ISSN 1338-130X.

[4] PATRÁŠ, V., 2009. Sociolingvistické aspekty elektronicky podmienenej komunikácie. Karviná: Studia Oeconomica. 149/155 p. ISBN 978-80-7248-522-2.

[5] http://www.markenlexikon.com/slogans_j.html

[6] BUZÁSSYOVÁ, K., 2003. K dimenziám slovnej zásoby. In: Internacionalizmy v nové slovní zásobě. Praha: ÚJČ AV ČR. s. 5-15. ISBN 80-86496-11-2. 